\section{Gordon Research Conference to Highlight High-Temperature Materials}

The Gordon Research Conference on "High-Temperature Materials, Processes, and Diagnostics," chaired by Nathan S. Jacobson of NASA Glenn Research Center and endorsed by the Materials Research Society, covers a range of topics in fundamental high-temperature science. It is scheduled for July 23-28, 2000 at Plymouth State College in Plymouth, New Hampshire. The conference will feature indepth presentations on the following areas: solid state reactions, thermodynamics / structure correlations, thermodynamic modeling, novel methods of high-temperature waste disposal, novel synthesis routes for ceramics and composites, gas/solid interactions, high-temperature device fabrication, and high-temperature fuel cell considerations. According to the Gordon Conference format, technical sessions are held in the mornings and evenings with the afternoons free for further discussion or enjoying New Hampshire.

In addition, a poster session will be organized for presentation of current research by interested attendees. Posters are solicited in all areas of high-temperature science.

Graduate student participation is encouraged and funding is available to cover the conference fees (registration, lodging, and meals) for a number of graduate students.

For more information, contact Jacobson at NASA Glenn Research Center, M.S. 106-1, 21000 Brookpark Rd., Cleveland, $\mathrm{OH} 44135$ USA; 216-433-5498; fax: 216433-5544; or e-mail nathan.s.jacobson@grc. nasa.gov; or see website http://www.grc. uri.edu/programs/2000/hightemp.htm (http://www.grc.uri.edu/programs / 2000/hightemp.htm).

\section{E-MRS/IUMRS-ICEM to be Held in Strasbourg, May 30-June 2}

The European Materials Research Society (E-MRS) will host the 7th International Union of Materials Research Societies International Conference on Electronic Materials (IUMRS-ICEM) on May 30-June 2 in Strasbourg, France. Along with ICEM, the E-MRS conference chairs P. Glasow of Germany and G. Crean of NMRC, Ireland, have incorporated the 6th TPP (Thermal Plasma Processes Conference), organized by the International Plasma Society, and the 6th IMF Workshop (Initiative for Inert Matrix Fuel) into the annual E-MRS Meeting. The program offers 18 symposia covering a broad range of cross-disciplinary advanced topics on materials, technologies, and devices, mainly for the area of Information Technology.

Symposia topics include Group III Nitrides, Photon-Induced Material Processing, Current Trends in Nanotechnologies, Epitaxial Nanometer Structures,
Optoelectronics, Rare-Earth-Doped Semiconductors III, Sub-Quarter-Micron Silicon Issues in the 200/300 mm Conversion Era, Advanced Characterization of Semiconductor Materials, Thin Film Chalcogenide Photovoltaic Materials, Thin Film Materials for Large Area Electronics, Crystal Chemistry of Functional Materials, Materials Issues for High-Temperature Superconductor Applications, and Materials Science with Ion Beams.

For general information regarding the conference contact the E-MRS General Secretary, P. Siffert, Conference Secretariat, E-MRS 2000 SPRING MEETING, BP 20, 67037 Strasbourg Cedex 2, France; 33-3-8810-65-43; fax: 33-3-88-10-63-43; emrs@ phase.c-strasbourg.fr; or see website www-emrs.c-strasbourg.fr/2000call.htm.

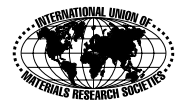

\begin{tabular}{|c|c|c|}
\hline \multicolumn{3}{|c|}{ MRS BUUETIN SEEKS IUMRS NEW S O N } \\
\hline $\begin{array}{l}\text { - Upcoming Meetings } \\
\text { - Conference Reports }\end{array}$ & $\begin{array}{l}\text { - Important Technical Developments } \\
\text { - Research N ews }\end{array}$ & $\begin{array}{l}\text { - Policy Issues } \\
\text { - Educational Initiatives }\end{array}$ \\
\hline \multicolumn{3}{|c|}{$\begin{array}{l}\text { MRS Bulletin, Materials Research Society } \\
\text { eystone Drive, W arrendale, PA 15086-7573 USA } \\
\text { @mrs.org or gabrielle.Iong@nist.gov; Fax: 724-779-8313 }\end{array}$} \\
\hline
\end{tabular}

Readers take note: THIS CONFERENCE IS FOR YOU

S1C Who: The Soclety of Vacuum Coaters Sogery What: 43rd SVC Annual Coarzes Technical Conference

SVC is a professlonal society devoted to the exchange of technical information related to the manufacture and production of thin film products prepared by PVD processes.

\section{Technical Sessions April 18-20}

- Vacuum Web Coating

- Decorative and Functional Coating

- Optical Coating

- Tribological \& Wear Coating

- Plasma Processing

- Process Control \& Instrumentation

- Large Area Coating

- Emerging Technologies

- New Products from Vendors

- "Meet the Experts Corner"

\section{Major Equipment Exhibit Aprli 18-19}

\section{SVC Education Program} April 15-20

- Vacuum Technology (4 courses)

- Optical Coatings (4 courses)

- Evaporation and Sputtering

- Sputter Deposition (2 courses)

- Basics of Vacuum Web Coating

- Mechanical Pumping Systems

- Evaporation as a Deposition Process

- Cathodic Arc Deposition of Hard Coatings

- Principles of Color Measurement

- Fundamentals of PVD Processing

- Material Science Aspects of Plasma Processing

- Hard Coatings New!

- Primer on System Applications New! of High Vacuum Pumps

- Cleaning and Contamination Control for PVD Systems

- Deposition \& Properties of ITO Coatings

- Optical Coating Problem-Solving using Analytical Techniques

- Non Conventional Plasma Sources

- PECVO

- Leak Detection Workshop

- Sputter Deposition in Manufacturing

When: April 15-20, 2000

Where: Adam's Mark Hotel Denver, CO

For more Inlormation contact:

Society of Vacuum Coaters

Telephone 505/856-7188

FAX 505/856-6716

E-mail 〈svcinfo\&svc.org>

Web Site <http:/hnnw.svc.org> 